Jpn. J. Oral Biol., $30: 550-558,1988$.

\title{
ORIGINAL
}

\section{Effects of adrenergic $\alpha$-agonists on the secretion of glycoproteins from the secretory cells of the rat submandibular gland}

\author{
Yoshiki Iwabuchi, Chihiro Aoki and Taizo Masuhara \\ Department of Dental Pharmacology, School of Dentistry at Niigata, \\ The Nippon Dental University, Niigata 951, Japan \\ [Accepted for publication: January 12, 1988〕
}

Key words : Rat submandibular segment/submandibular saliva/glycoprotein species / $\alpha$-agonists

\begin{abstract}
The effects of six different $\alpha$-agonists : methoxamine (MET), phenylephrine (PHE), metaraminol (MTA), naphazoline (NAP), oxymetazoline (OXY), and clonidine (CLO), each administered at a dose of $8 \mathrm{mg} / \mathrm{kg}$, on the secretion of glycoprotein (GP) and fluid from the submandibular glands were studied in anesthetized rats. Salivation elicited by the drugs occurred 5-10 min after administration of MET and within about $5 \mathrm{~min}$ in the other cases. The order of potency of effects on salivation from the submandibular gland was $\mathrm{PHE}>\mathrm{MET}>\mathrm{MTA} \gg \mathrm{NAP} \fallingdotseq \mathrm{CLO} \doteqdot \mathrm{OXY}$. The concentrations of protein in saliva evoked by MET, PHE, and MTA were significantly higher than those in saliva evoked by NAP, OXY and CLO. The electrophoretic profiles of GP in submandibular saliva elicited in response to the six $\alpha$-agonists showed two bands which corresponded to GP I (130 KDa) and GP IV $(21.5 \mathrm{KDa})$, characteristically present in the acinus, and one band which corresponded to GP III (31 $\mathrm{KDa}$ ) characteristically present in the granular tubules. The relative amounts of band III expressed as a percentage of total glycoprotein in saliva evoked by MET, PHE, MTA, NAP, OXY, and CLO were $63.5 \pm 4.4,43.2 \pm 2.4,27.9 \pm 5.3,11.8 \pm 0.6,24.9 \pm 4.0$, and $17.5 \pm 0.8$, respectively. These results suggest that MET, PHE, and MTA affect the granular tubules predominantly, whereas NAP, OXY, and $\mathrm{CLO}$ affect both the acinus and granular tubules. Furthermore, $\alpha$-adrenoceptors which mediate secretion of glycoprotein and fluid in response to these drugs appear, thus, to be mainly of the $\alpha_{1}$-subtype.
\end{abstract}

\section{Introduction}

$\alpha$-adrenoceptors are classified as $\alpha_{1}$ and $\alpha_{2}$ based on pharmacological differences in the relative affinities and potencies of agonists and antagonists to the receptors ${ }^{1-3)}$. The $\alpha_{1}$ adrenergic agonists, such as methoxamine ${ }^{4}$ and phenylephrine $e^{4,5)}$, and the $\alpha_{2}$-adrenergic agonists, such as clonidine ${ }^{6}$, and oxymetazo$\operatorname{line}^{7)}$, elicit different species of protein from rat submandibular glands. There is evidence that $\alpha_{1}$-adrenergic agonists act mainly on granular tubules ${ }^{8,9)}$, but the site of action of $\alpha_{2}$ adrenergic agonists has not yet been established in the rat submandibular gland.

We reported previously that species of secretable glycoproteins in the rat submandibular gland differ markedly between acini and granular tubules ${ }^{10)}$ and that characteristic glycoproteins in acini are secreted into saliva as a result of treatment with $\beta$-adrenergic agonists, such as isoproterenol ${ }^{11,12)}$, dobutamine ${ }^{12}$ and terbutaline ${ }^{12}$, and also by cholinergic agonists, such as acetylcholine, methacholine, carbachol, bethanechol ${ }^{13)}$, and pilocarpine $^{14)}$, as well as by polypeptides such as substance $\mathrm{P}^{15}$, and small doses of dopamine $^{16)}$. By contrast, glycoproteins charac teristic of the granular tubules are secreted in response to $\alpha_{1}$-adrenergic agonists, such as methoxamine at optimal doses ${ }^{11,17,18)}$ and dopamine at high doses ${ }^{16}$.

Present study was carried out to locate the site of action of methoxamine, phenylephrine, metaraminol, naphazoline, oxymetazoline, and clonidine in the secretory cells of the 
rat submandibular gland, through analysis of the marker glycoproteins in the saliva elicited by administration of these drugs to rats. We also monitored the flow rate and concentration of protein in saliva elicited in response to the various drugs.

\section{Materials and Methods}

\section{Collection of submandibular saliva}

Male Sprague-Dawley rats, ten weeks of age, were deprived of food but given water ad libitum for the 24 hours prior to examination. Each rat was anesthetized with sodium pentobarbital ( $50 \mathrm{mg} / \mathrm{kg}$ b. wt., i.p.), and placed on a heating pad maintained at $37^{\circ} \mathrm{C}$. The excretory ducts of the sublingual gland were ligated after being separated from the adherent tissues around the submandibular gland. The trachea was cannulated with a polyethylene tube (MRC, $2 \times 2.7 \mathrm{~mm}$ ). Methoxamine, phenylephrine, metaraminol, naphazoline, oxymetazoline, and clonidine were each administered intraperitoneally at a dose of $8 \mathrm{mg} / \mathrm{kg}$ b. wt. Submandibular saliva was collected from the tip of the ductal cannula with a capillary micropipette (Drummond Microcaps, 10 and $20 \mu l$ ) for periods of $5 \mathrm{~min}$ over the course of $30 \mathrm{~min}$. At the end of the collection of saliva, the submandibular glands were carefully removed and the flow rate were then calculated as the volume of fluid elicited per minute per milligram of wet weight of each gland.

\section{Preparation of functional segments}

Parenchymal components from the rat submandibular gland were isolated by the method of Masuhara and Iwabuchi ${ }^{10}$ as follows. Rats were anesthetized with pentobarbital (50 $\mathrm{mg} / \mathrm{kg}$, i.p.) and the submandibular gland was perfused via the carotid artery with a solution which consisted of $0.1 \%$ collagenase (Sigma, Type II), $1.0 \mathrm{mM} \mathrm{CaCl}{ }_{2}$ and $0.1 \%$ bovine serum albumin in modified Hank's medium. The submandibular gland was immediately removed, sliced and then incubated for 120 $\min$ at $37^{\circ} \mathrm{C}$ with the same collagenase solution under an atmosphere of $95 \% \mathrm{O}_{2}$ plus $5 \%$ $\mathrm{CO}_{2}$. The slices were rinsed with ice-cold modified Hank's solution to remove collagenase and then transferred to small, siliconized petri dishes. Each dish was put on a cold plate maintained at $4^{\circ} \mathrm{C}$. Each segment of the acini and granular tubules was dissected out with needles under a stereomicroscope and each of the dissociated segments was collected in a siliconized capillary tube (Drummond Microcaps, $50 \mu \mathrm{l}$ ).

SDS-polyacrylamide micro-disc electrophoresis

Each sample of segment was dissolved in an equal volume of $6 \%(\mathrm{w} / \mathrm{v})$ sodium dodecyl sulphate (SDS) solution which contained $10 \%$ 2 -mercaptoethanol, and was heated at $90^{\circ} \mathrm{C}$ for $3 \mathrm{~min}$. The protein content of each of the samples was determined by the method of Lowry et al. ${ }^{19)}$. Each sample of saliva, containing 0.25 or $0.5 \mathrm{mg}$ protein per $\mathrm{m} l$ in a solution of $1 \%$ SDS, $5 \% 2$-mercaptoethanol and $20 \%$ glycerol, was heated at $100^{\circ} \mathrm{C}$ for $5 \mathrm{~min}$. One $\mu l$ of this sample solution was applied to the top of a $4-40 \%$ continuous gradient polyacrylamide disc gel packed in a $10 \mu l$ capillary tube (Brand, intra END), as described by Rüchel et al. ${ }^{20)}$. Electrophoresis was performed at room temperature at $60 \mathrm{~V}$ for $60 \mathrm{~min}$ in a solution that contained 50 $\mathrm{mM}$ Tris-glycine buffer ( $\mathrm{pH} 8.4)$ in $0.1 \%$ SDS. Gels were stained either with $0.2 \%$ Coomassie Brilliant Blue R-250 for proteins or with periodic-Schiff's reagent (PAS) for glycoproteins and the gels were analyzed spectrophotometrically with a microdensitometer (Joyce-Loebl 3CS), operated at a wave length of $595 \mathrm{~nm}$ for gels stained with Coomassie Blue, and at $550 \mathrm{~nm}$ for gels stained with PAS. The relative intensities of the glycoprotein bands were measured by planimeter (Planimex 25, Japan Regurater).

\section{Drugs}

Drugs used were methoxamine hydrochloride (Mexan, Nippon Shinyaku), L-phenylephrine hydrochloride (Sigma), metaraminol bitartrate (Araminon, Bunyu Pharmaceutical), naphazoline hydrochloride (Sigma), oxymetazoline hydrochloride (Sigma) and clonidine hydrochloride (Merck).

\section{Results}

Secretory responses of submandibular
glands

The flow rates of saliva elicited from submandibular glands after intravenous administra- 


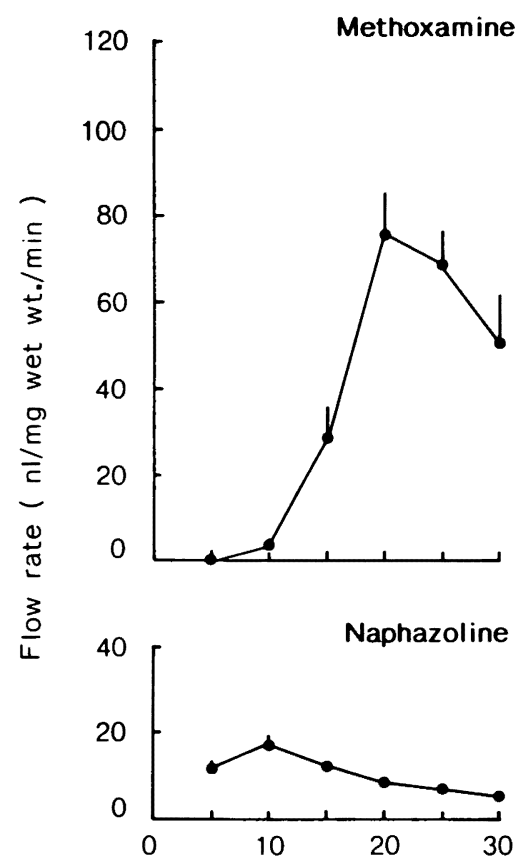

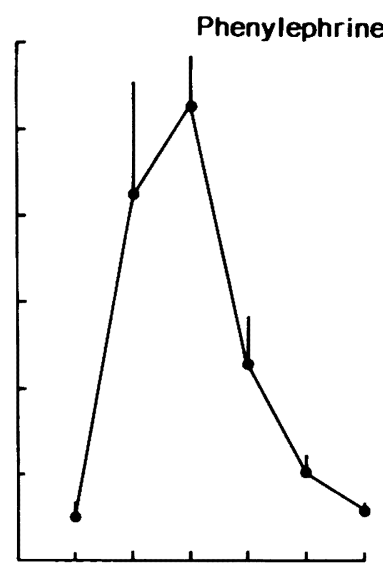
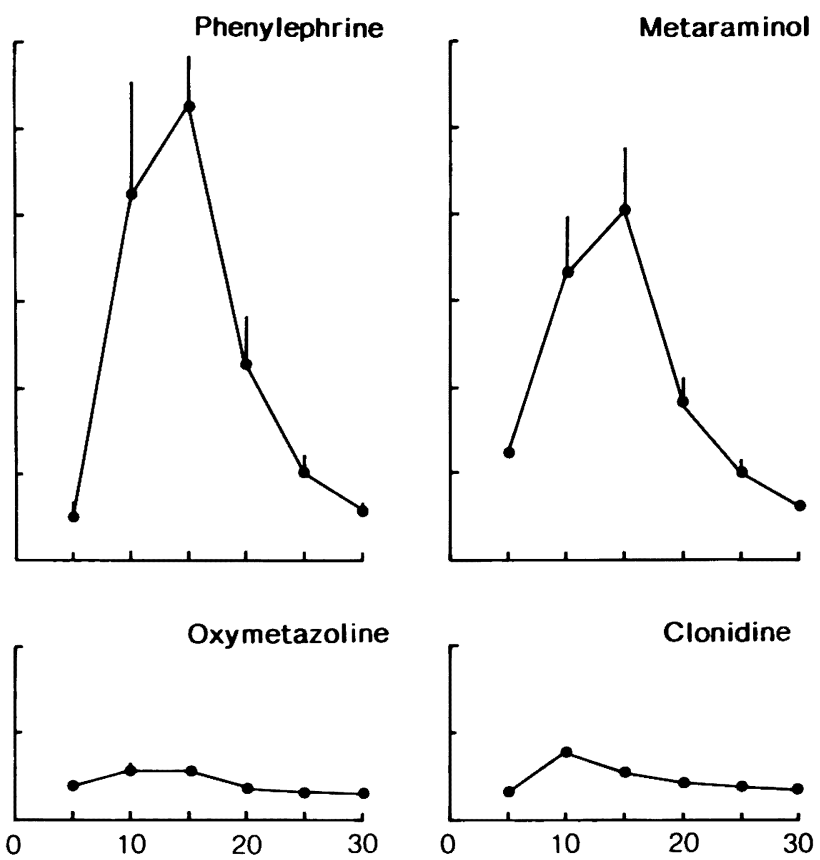

Time $(\min )$

Fig. 1 The flow rates of saliva secreted from rat submandibular glands after administration of six $\alpha$ agonists. Each agonists was injected intraperitoneally at a dose of $8 \mathrm{mg} / \mathrm{kg}$. Each point represents the mean \pm S.E. of results from six animals.

tion of the six $\alpha$-adrenergic agonists, methoxamine, phenylephrine, metaraminol, naphazoline, oxymetazoline and clonidine, each at a dose of $8 \mathrm{mg} / \mathrm{kg}$, are shown in figure 1 . Salivation began $5-10 \mathrm{~min}$ after administration of methoxamine and after $0-5 \mathrm{~min}$ in the case of the other five agonists. The salivary flow rates reached a maximal level at $15-20$ min after administration of methoxamine, at 10-15 min after administration of phenylephrine and metaraminol, and at 5-10 min after administration of naphazoline, clonidine, and oxymetazoline. After the maximal response was obtained, the flow rates decreased rapidly in the case of phenylephrine and metaraminol, but decreased gradually in the case of methoxamine, naphazoline, and oxymetazoline. The total volumes of saliva secreted from submandibular glands during the $30 \mathrm{~min}$ after administration of methoxamine, phenylephrine, metaraminol, naphazoline, oxymetazoline, and clonidine, expressed per $100 \mathrm{mg}$ wet gland, were $119.6 \pm 11.8,138.1 \pm 9.8$,
$109.8 \pm 15.7,31.0 \pm 3.3,24.3 \pm 2.3$, and $27.5 \pm$ $1.2 \mu l$, respectively (Fig. 2).

Protein concentration and total amounts of protein of saliva secreted from subman. dibular glands

The concentrations of protein in the saliva secreted from the submandibular glands during the $30 \mathrm{~min}$ after administration of meth oxamine, phenylephrine, metaraminol, naphazoline, oxymetazoline, and clonidine, were $6.6 \pm 1.4,12.8 \pm 2.3,13.0 \pm 0.9,2.5 \pm 0.2,3.0 \pm$ 0.5 , and $2.3 \pm 0.2 \mathrm{mg} / \mathrm{ml}$, while the total amounts of protein, expressed per $100 \mathrm{mg}$ wet gland, were $0.76 \pm 0.18,1.79 \pm 0.35$, $1.39 \pm 0.16,0.07 \pm 0.01,0.07 \pm 0.01$, and $0.06 \pm$ $0.01 \mathrm{mg}$, respectively (Fig. 4).

Electrophoretic profiles of the glycoproteins and proteins

The typical electrophoretic patterns of gly. coproteins, stained with PAS, in the submandibular saliva elicited during the $30 \mathrm{~min}$ after administration of the six $\alpha$-agonists are shown in figure 5. Methoxamine- and phe- 


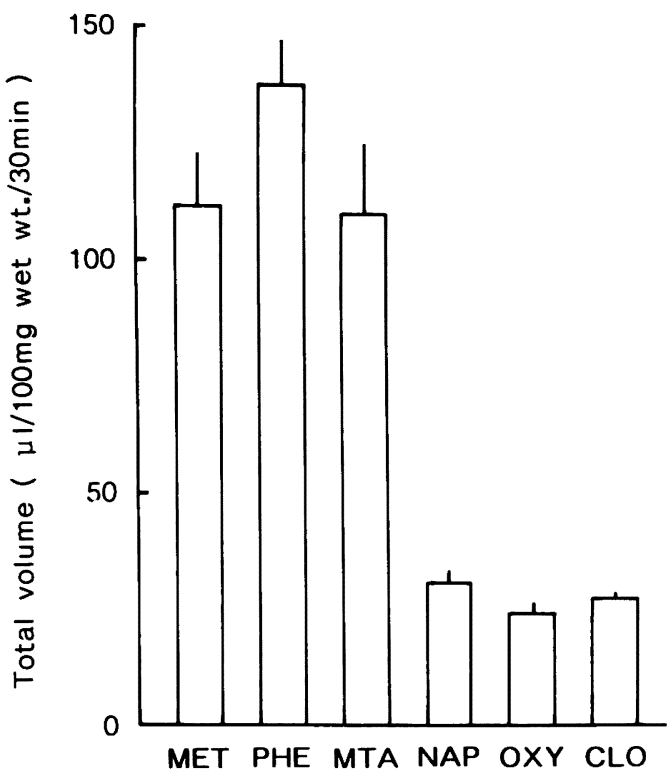

Fig. 2 The volume of saliva secreted from rat submandibular glands after administration of $\operatorname{six} \alpha$-agonists. Total volume is represented as $\mu l$ of saliva secreted per $100 \mathrm{mg}$ wet weight of the gland for the $30 \mathrm{~min}$ period which followed i.p. administration of each drug at a dose of $8 \mathrm{mg} / \mathrm{kg}$. MET, methoxamine; PHE, phenylephrine; MTA, metaraminol : NAP, naphazoline ; OXY, oxymetazoline; CLO, clonidine. Each point represents the mean $\pm \mathrm{S}$. $\mathrm{E}$. of results from six animals.

nylephrine-evoked saliva showed a heavily stained band III, and two lightly stained bands, I and IV. Metaraminol-evoked saliva showed two heavily stained bands, I and III, and one lightly stained band IV. Naphazoline-, oxymetazoline-, and clonidine-evoked saliva showed three stained bands, I, III, and IV, but band III in each case was less intensely stained than in methoxamine- and phenylephrine-evoked saliva. Analysis of the electrophoretic patterns of glycoproteins from the secretory segments isolated from the submandibular gland of the normal rat showed that the acinar segments contained one major band, band (I), and three minor bands, bands (II), (III), and (IV), whereas the segments of granular tubules contained one major band, band (III), and two minor bands,

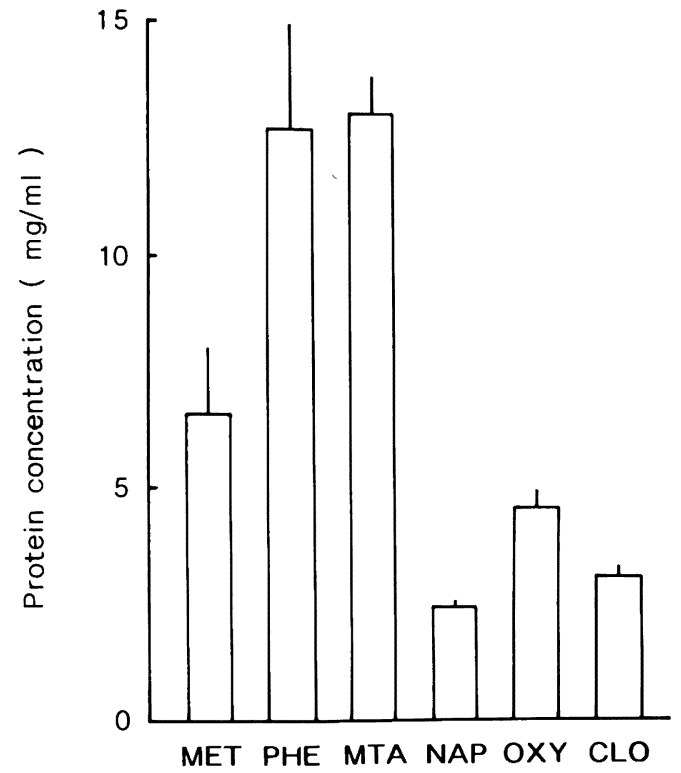

Fig. 3 The concentration of protein in saliva secreted from rat submandibular glands after administration of six $\alpha$-agonists. Concentrations of protein were determined in saliva elicited during the $30 \mathrm{~min}$ after intraperitoneal injection of drugs at a dose of $8 \mathrm{mg} / \mathrm{kg}$. MET, methoxamine; PHE, phenylephrine; MTA, metaraminol ; NAP, naphazoline ; OXY, oxymetazoline; CLO, clonidine. Each point represents the mean \pm S.E. of results from six animals.

bands, (I ) and (II), as reported previously ${ }^{10 \text { ) }}$ (data not shown). When saliva elicited by administration of each of the six $\alpha$-adrenergic agonists was combined with samples of the acinus or granular tubules, and co-electrophoresed, bands I and IV of saliva were electrophoretically coincident with the main bands (I) and (IV) in the acinar sample, while band III was electrophoretically identical to the major band in the granular tubules (data not shown). The apparent molecular weights of proteins in bands I, III and IV were $130 \mathrm{~K}$, $31 \mathrm{~K}$ and $21.5 \mathrm{~K}$ daltons, as reported previously ${ }^{10}$.

The relative amounts, expressed as a percentage of total glycoprotein, of the glycoprotein bands I, III, and IV, in saliva elicited from submandibular glands by administration of the six $\alpha$-adrenergic agonists, are shown 


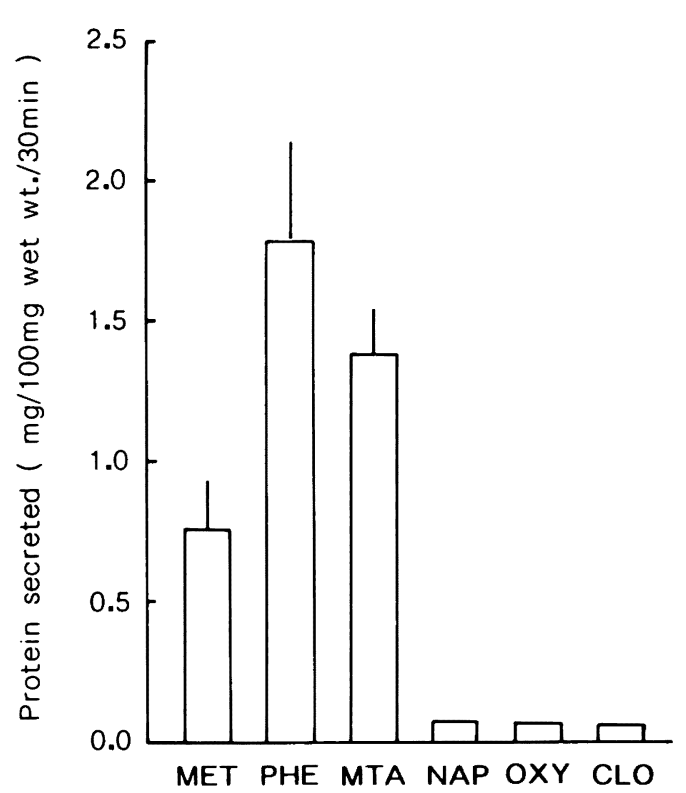

Fig. 4 The total amounts of protein in saliva secreted from rat submandibular glands after administration of six $\alpha$-agonists. Total amounts of protein secreted are calculated from total volumes of secreted saliva and concentrations of protein in saliva. MET, methoxamine; PHE, phenylephrine; MTA, metaraminol ; NAP, naphazoline; OXY, oxymetazoline : CLO, clonidine. Each point represents the mean \pm S.E. of results from six animals.

in figure 6. For saliva evoked by administration of methoxamine, phenylephrine, metaraminol, naphazoline, oxymetazoline, and clonidine, the relative amounts of band III were $63.5 \pm 4.4, \quad 43.2 \pm 2.4, \quad 27.9 \pm 5.3, \quad 11.8 \pm 0.6$, $24.9 \pm 4.0$, and $17.5 \pm 0.8 \%$ and those of band I were $9.6 \pm 1.0,22.0 \pm 3.6,36.0 \pm 4.5,32.2 \pm$ $2.8,25.4 \pm 1.4$, and $23.0 \pm 1.4 \%$, respectively. The relative amount of glycoprotein in band $\mathrm{IV}$, in the case of each of the six $\alpha$-agonists, was significantly lower than that of band I .

The profiles of proteins in methoxamineevoked saliva stained with Coomassie Blue were similar to those of phenylephrine-evoked and metaraminol-evoked saliva, whereas that of clonidine-evoked saliva was similar to those of oxymetazoline- and naphazoline-evoked saliva (data not shown). The protein band corresponding to glycoprotein band I was stained very slightly with Coomassie Blue, whereas the proteins which corresponded to glycoprotein bands III and IV, in particular band III, were stained strongly.

\section{Discussion}

When six $\alpha$-agonists were administered intraperitoneally at individual doses of $8 \mathrm{mg} / \mathrm{kg}$, the relative potencies of the agonists in eliciting salivation from rat submandibular gland were phenylephrine $>$ methoxamine $>$ metaraminol $\gg$ naphazoline $=$ clonidine $\fallingdotseq$ oxymetazoline, as shown in figure 1. Abe and Dawes have observed that the volume of saliva elicited from submandibular glands in response to phenylephrine and to methoxamine is greater in response to phenylephrine than to methoxamine when both drugs are administered intraperitoneally at a dose of $6 \mathrm{mg} / \mathrm{kg}^{4}$. Green et al. have shown that methoxamine evokes much more saliva than noradrenaline or naphazoline ${ }^{21}$. According to Langer ${ }^{3)}$, methoxamine and phenylephrine have a high affinity for the $\alpha_{1}$-adrenoceptors, while clonidine and oxymetazoline have higher affinity for the $\alpha_{2}$-receptors than for the $\alpha_{1}$-adrenoceptors. Naphazoline has about equal affinity for the both the $\alpha_{1}$-and the $\alpha_{2}$-adrenoceptors. It is generally recognized that the order of relative potencies of these agonists is methoxamine $>$ phenylephrine for $\alpha_{1}$-receptors, and clonidine>oxymetazoline for $\alpha_{2}$-receptors ${ }^{3}$. Our data are consistent with earlier data, and suggest that the $\alpha$-adrenoceptors that mediate secretion of saliva are mainly of the $\alpha_{1}$. subtype. The flow rates and volumes of saliva elicited by $\alpha_{1}$-adrenergic agonists were considerably larger than those elicited by $\beta$ adrenergic agonists, such as isoproterenol and dobutamine ${ }^{12}$, but considerably lower than those elicited by cholinergic agents, such as pilocarpine $^{14}$, acetylcholine, methacholine, bethanechol, and carbachol ${ }^{13)}$.

The concentrations of proteinin saliva elicited from submandibular glands by administration of $\alpha_{1}$-adrenergic agonists were significantly higher than those in saliva elicited by $\alpha_{2}$-adrenergic agonists, as shown in figure 5.: The concentration in phenylephrineevoked saliva was significantly higher than in methoxamine-evoked saliva. A similar tendency was observed by Abe and Dawes ${ }^{51}$. 


\section{Naphazoline}

\section{Methoxamine}

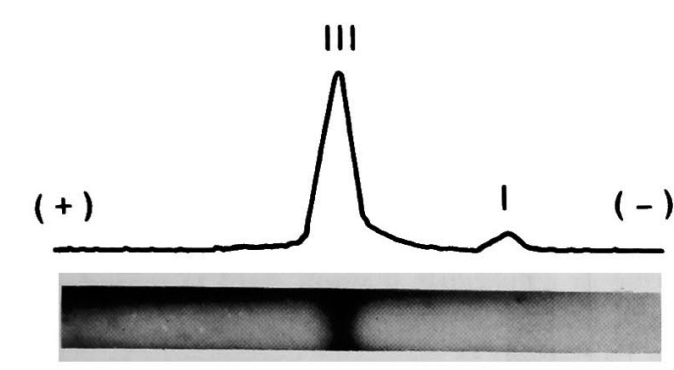

Phenylephrine

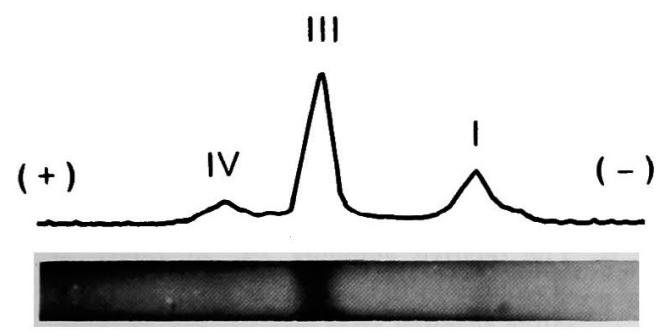

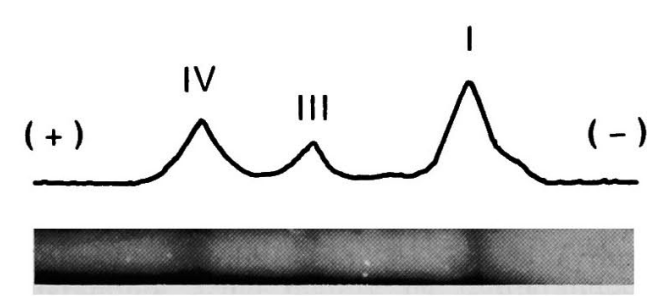

Oxymetazoline

\section{Metaraminol}

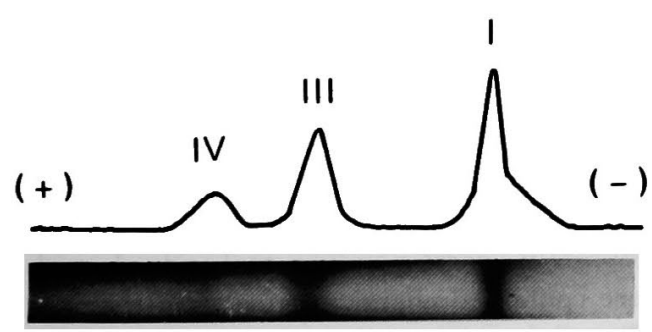

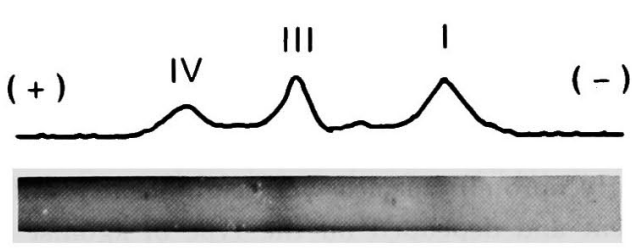

Fig. 5 The typical densitometric scans of glycoproteins from submandibular saliva secreted after i.p. administration of six $\alpha$-agonists. Saliva elicited during the $30 \mathrm{~min}$ after intraperitoneal injection of drugs at dose of $8 \mathrm{mg} / \mathrm{kg}$ was used as sample. Samples containing $0.5 \mu \mathrm{g}$ of protein were applied to gels. After electrophoresis, gels are stained with PAS. Electrophoresis was performed as described in materials and methods.

Furthermore, the concentration of protein in metaraminol-evoked saliva was similar to that in phenylephrine-evoked saliva. It is well known that stimulation of $\alpha$-adrenoceptors produces a moderate volume of saliva that is low in protein, whereas stimulation of $\beta$-adrenergic receptors elicits a small volume of saliva rich in protein ${ }^{4,22,23)}$. Thus, the high concentration of protein in phenylephrine- and metaraminol-evoked saliva observed in this experiment are probably the result of stimulation by these drugs of $\beta$-adrenoceptors 
in acinar cells of submandibular glands. By contrast, the concentrations of protein in naphazoline-, oxymetazoline-, and clonidineevoked saliva were about $34-45 \%$ of that in methoxamine-evoked saliva. It is, therefore, proposed that the action of these three drugs on the rat submandibular gland differs from the action of methoxamine.

The electrophoretic patterns of proteins in saliva elicited by the six drugs were significantly different from each other. Among these drugs, clonidine at a dose of $10 \mathrm{mg} / \mathrm{kg}^{6}$ ) and oxymetazoline at doses of $3-20 \mathrm{mg} / \mathrm{kg}^{7)}$ elicit significantly different types of protein from those elicited by other $\alpha_{1^{-}}, \beta-$, and cholinergic agonists, when these drugs are administered intraperitoneally. Thus, the site of action of $\alpha_{2}$-adrenergic agonists in the rat submandibular gland is different from that of $\alpha_{1}$-adrenergic agonists. Similar differences in types of salivary protein were also evident in our experiment, as shown in figure 5 . Moreover, the electrophoretic patterns of the glycoprotein species were significantly different and depended on the type of agonist involved, as shown in figure 5 . From these profiles, the relative amounts of glycoprotein bands I, III, and IV were calculated from data obtained from six animals per group and are shown in figure 6. As reported previously, the glycoprotein species corresponding to glycoprotein band III is contained characteristically in granular tubules ${ }^{10)}$ and this glycoprotein is predominantly secreted in saliva elicited by methoxamine but not by cholinergic $^{13,14}$ or $\beta$-adrenergic agonists ${ }^{11,12)}$. The secretion of glycoproteins induced by methoxamine can be completely inhibited by the $\alpha_{1}$-adrenergic antagonist, prozosin ${ }^{18)}$. However, the relative amount of glycoprotein band III in phenylephrine-evoked saliva was significantly lower than that in methoxamine-evoked saliva. There is evidence from Izumi $^{24}$ that the releasing ability of a kallikrein-like esterase from dispersed cells of the rat submandibular gland is higher after treatment with methoxamine than with phenylephrine. From these results and our present results, it is proposed that the affinity of methoxamine for $\alpha_{1}$-adrenoceptors in granular tubules of the rat submandibular gland is

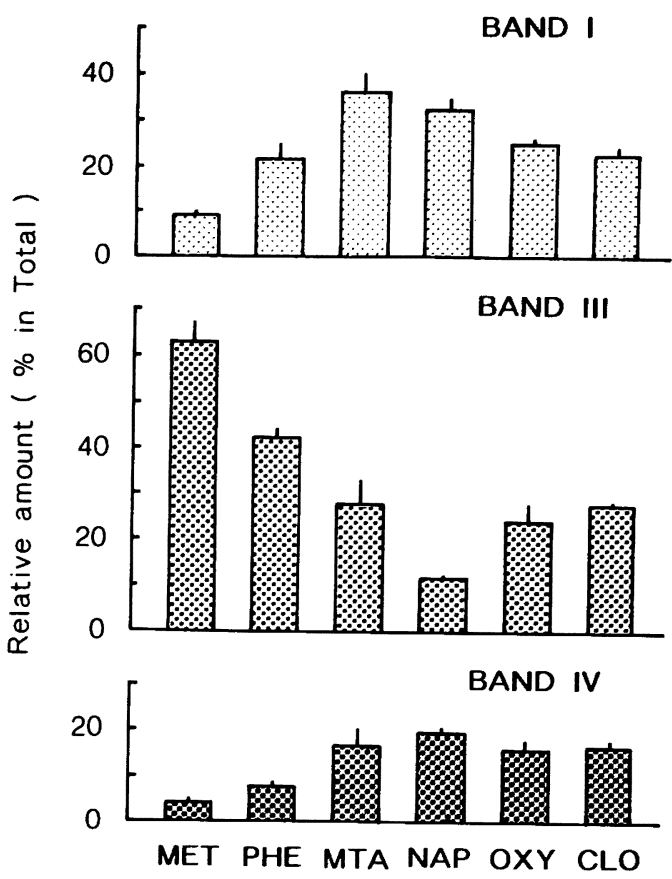

Fig. 6 The relative amounts (\% of total) of glycoprotein in bands from submandibular saliva secreted after intraperitoneal injection of six $\alpha$-agonists. MET, methoxamine; PHE, phenylephrine; MTA, metaraminol ; NAP, naphazoline ; OXY, oxymetazoline; CLO, clonidine. Each point represents the mean $\pm S$.E. of results from six animals.

higher than that of phenylephrine. However, the relative amounts of glycoprotein bands I and IV in phenylephrine-evoked saliva were significantly higher than those in methoxamine-evoked saliva. Because both species of glycoprotein, corresponding to bands I and IV, are contained characteristically in the acinus $^{(0)}$ and found in saliva elicited by various $\beta$-adrenergic agonists ${ }^{11,12)}$, as described previously, phenylephrine, which generates band I and IV in the glycoprotein profiles, appears to stimulate $\beta$-adrenergic receptors of the acinus, as observed with the heart ${ }^{25)}$. Metaraminol may act on acinar cells in the same manner, but its action is stronger than that of phenylephrine. Glycoproteins in naphazoline-, oxymetazoline-, and clonidine-evoked nssaliva gave similar patterns, but these patterns differed significantly from those of saliva 
elicited by methoxamine, phenylephrine, and metaraminol, with respect to the relative amounts of glycoprotein bands I and IV. Clonidine is usually considered to be a preferential agonists of $\alpha_{2}$-adrenoceptors at both peripheral and central sites $^{26}$. However, it has also been reported that clonidine at low doses mainly stimulates $\alpha_{2}$-adrenoceptors, whereas at high doses it stimulates $\alpha_{1}$-adrenoceptor in addition to $\alpha_{2}$-adrenoceptors, in studies of vasopressor responses of the pithed $\mathrm{rat}^{27)}$ and secretion of ACTH in the hypothalamic deafferentated $\mathrm{rat}^{28)}$. Thus, the appearance of glycoprotein band III in saliva after administration of clonidine at the high dose of 8 $\mathrm{mg} / \mathrm{kg}$ may be due to stimulation of $\alpha_{1}$-adrenoceptors in granular tubules, but clonidine must simulate some sort of receptor in the acinus, because clonidine stimultaneously causes secretion of glycoproteins I and IV. However, we can not determine from our present data the nature of the receptors which mediate secretion of the glycoproteins in bands I and IV from acinar cells after admin. istration of these $\alpha_{2}$-adrenergic agonist. Further studies are necessary to ascertain the nature of receptors that mediate the secretory action of $\alpha_{2}$-adrenergic agonists on acinar cells and cells of the granular tubules.

In this study, we tested six adrenergic ag. onists. Methoxamine, phenylephrine and metaraminol acted mainly on the granular tubules, while naphazoline, oxymetazoline, and clonidine acted both on the acinus and the granular tubules.

\section{Acknowledgements}

This study was supported in part by a Grantin-Aid for Scientific Research (No. 60480404 and No. 62570845) from the Ministry of Education, Science and Culture of Japan.

抄録：頡下腺からの糖蛋白と唾液分泌汶対する各 $8 \mathrm{mg} / \mathrm{kg}$ (i.p.) methoxamine (MET), phenylephrine (PHE), metaraminol(MTA), naphazoline (NAP), oxymetazoline (OXY) および clonidine (CLO)の 6 種の $\alpha$ 作働薬の影響について麻酔ラットを用いて研究した。喠液分泌は, MET で投与後 5-10分, その他 の作働薬で投与後 $0-5$ 分でみられた。唾液分泌の potency は, PHE $>$ MET $>$ MTA 》NAP $=$ CLO $=$ OXY の順であった。MET, PHE および MTA 分泌唾液の蛋白濃度は, NAP, OXY および CLO 分泌唾 液より明らかに高かった。頻下腺喠液の糖蛋白泳動像は，6種の作働薬とも腺房に特徴的に含まれた GP I (130KDa) および GP IV (21.5KDa) の 2 本の Band と顆粒管に特徵的に含まれた GP III (31KDa)の Band を示したが, MET, PHE, MTA, NAP, OXY および CLO 分泌唾液の糖蛋白 Band III の全糖蛋白 に占める相対量は，それぞれ $63.5 \pm 4.4 ， 43.2 \pm 2.4,27.9 \pm 5.3,11.8 \pm 0.6,24.9 \pm 4.0$ および $17.5 \pm 0.8 \%$ て あった。以上の成績は，唾液分泌に関連するアドレナリン性 $\alpha$-受容体は主に $\alpha_{1}$-サブタイプであり, MET, PHE および MTA は主に顆粒管に，NAP，OXY および CLO は腺房と顆粒管に作用することを示唆す る。

\section{References}

1) Langer, S. Z.: Presynaptic regulation of catecholamine release. Biochem. Pharmacol. 23 : 1793-1800, 1974.

2) Starke, K. and Langer, S. Z. : A note on terminology for presynaptic receptors. In Presynaptic Receptors, Advances in the Biosciences, Edited by Langer, S. Z., Starke, K. and Dubocovich, M. L., vol. 18, pp. 13, Pergamon Press, Oxford, 1979.

3) Langer, S. Z.: Presynaptic regulation of the release of catecholamine. Pharmacol. Rev. 32 : 337-362, 1980.

4) Abe, K. and Dawes, C. : Secretion of protein by the submandibular glands of the rat, mouse, and hamster in response to various parasympatho- and sympatho-mimetic drugs.
J. Dent. Res. 61 : 1454-1457, 1982.

5) Abe, K., Yoneda, K., Fujita, R., Yokota, Y. and Dawes, C.: The effects of epinephrine, norepinephrine and phenylephrine on the types of proteins secreted by rat salivary glands. J. Dent. Res. 59 : 1627-1634, 1980.

6) Oikawa, M. : Functional relationships between saliva secretion by the rat submandibular glands and their $\alpha_{1}$-adrenoceptors. Jpn. J. Oral Biol. 25 : 656-681, 1983 (in Japanese).

7) Abe, K. and Dawes, C.: The effects of oxymetazoline on secretion of protein and some electrolytes by rat submandibular and parotid glands. Comp. Biochem. Physiol. $[80$ C] : 347-353, 1985.

8) Фrstavik, T. B. and Gautvik, K. M. : Regulation of salivary kallikrein secretion in the rat submandibular gland. Acta Physiol. 
Scand. $100: 33-44,1977$.

9) Simson, J. A. V., Spicer, S. S., Chao, J., Grimm, L., Margolius, H. S. : Kallikrein localization in rodent salivary glands and kidney with the immunoglobulin-enzyme bridge technique. J. Histochem. Cytochem. 27 : 1567-1576, 1979.

10) Masuhara, T. and Iwabuchi, Y. : Micro-discelectrophoretic study on glycoproteins of parenchymal components dissociated from rat submandibular gland. Jpn. J. Oral Biol. 25 : 1177-1180, 1983.

11) Iwabuchi, Y., Aoki, C. and Masuhara, T. : Effects of adrenergic agents on glycoprotein secretion from acini and granular convoluted tubules of the rat submandibular gland. Jpn. J. Oral Biol. 27 : 741-745, 1985.

12) Iwabuchi, Y., Aoki, C. and Masuhara, T. : Effects of $\hat{i}_{1}$ - and $\beta_{2}$-adrenergic drugs on gly. coprotein secretion from the functional seg. ments of rat submandibular glands. Jpn. J. Pharmacol. $40:$ 180, 1986.

13) Aoki, C., Iwabuchi, Y. and Masuhara, T. : The effect of cholinergic drugs on glycoprotein secretion from the functional segments of rat submandibular gland. Jpn. J. Pharma. col. 40 : 184, 1986.

14) Masuhara, T. and Iwabuchi, Y.: Characterization of glycoproteins in submandibular acinus and saliva of rats elicited by pilocarpine. Jpn. J. Oral Biol. 26 : 280-283, 1984.

15) Iwabuchi, Y., Aoki, C. and Masuhara, T. : Effects of substance $P$ on glycoprotein secretion from acinar cells of the rat submandibular gland. Jpn. J. Pharmacol. 42 : 453-456, 1986.

16) Iwabuchi, Y., Aoki, C. and Masuhara, T. : Effects of dopamine on the secretion of gly. coproteins from the functional segments of the rat submandibular gland. Jpn. J. Pharmacol. 44 : 149-158, 1987.

17) Iwabuchi, Y., Aoki, C. and Masuhara, T. : Secretory patterns of characteristic glycoprotein species from segments of the rat submandibular gland following methoxamine stimulation. Jpn. J. Oral Biol. $27: 1267-$ 1271, 1985.

18) Iwabuchi, Y., Aoki, C. and Masuhara, T. : Effects of adrenergic antagonists on glycoprotein secretion from granular convoluted tubules of the rat submandibular gland induced by methoxamine. Jpn. J. Oral Biol. 28 : 761-765, 1986
19) Lowry, O. H., Rosebrough, N. J., Farr, A. L. and Randall, R.J. : Protein measurement with the Folin phenol reagent. J. Biol. Chem. 193 : 265-275, 1951.

20) Rüchel, R., Mesecke, S., Wolfrum, D. I. and Neuhoff, V.: Mikroelektrophorese an Kontinuierlichen Polyacrylamide Gradiented Gelen I . Herstellung und Eigenschaften von Gelgradienten in Kapillaren; iher Anwendung zur Proteinfraktionierung und Molgewichts-bestimmung. Hoppe-Seyler's Z. Physiol. Chem. 354 : 1351-1368, 1973.

21) Green, G. J., Wilson, H. and Yates, M. S. : The mechanism of the clonidine-induced reduction in peripheral parasympathetic submaxillary salivation. Eur. J. Pharmacol. 56 : 331-336, 1979.

22) Martinez, J. R., Quissell, D. O., Wood, D. L. and Giles, M. : Abnormal secretory response to parasympathomimetic and sympathomimetic .mulation from the submaxillary gland of rats treated with reserpine. J. Pharmacol. Exp. Ther. 194 : 384-395, 1975.

23) Young, J. A. and von Lennep, E. W. : Transport in salivary and salt glands: salivary glands. In Membrane Transport in Biology. ed. by Giebish, G., Springer Verlag, New York. 4 : 563-574, 1979.

24) Izumi, H. : Release of kallikrein-like esterase and tonin from dispersed cells of the rat submandibular gland. Br. J. Pharmacol. 82 : 175-182, 1984.

25) Malindzak, G. S., Jr., von Dyke, A. H., Green, H. D. and Meredith, J. H. : Alpha and beta adrenergic receptors in the coronary vascular bed. Arch. Int. Pharmacodyn. 197 : 112-122, 1972.

26) Schmitt, H. : The Pharmacology of Clonidine and Related Products. In: Antihypertensive Agents, ed. by Gloss, F., SpringerVerlag, Berlin-Heidelberg-New York, pp. 299-378, 1977.

27) Timmermans, P. B. M. W. M. and van Zwieten, P. A. : Postsynaptic $\alpha_{1}$ - and $\alpha_{2}$ adrenoceptors in the circulatory system of the pithed rat: selective stimulation of the $\alpha_{2}$-type by B-HT933. Eur. J. Pharmacol. 63 : 199-202, 1980.

28) Shimizu, K. : Effect of $\alpha_{1}$ - and $\alpha_{2}$-adrenoceptor agonists and antagonists on ACTH secretion in intact and in hypothalamic de afferentated rats. Jpn. J. Pharmacol. 36 : 23-33, 1984. 